\title{
Gastric conduit ischemia: Never a good thing, no matter when it happens
}

\author{
Victor A. Ferraris, MD, PhD
}

\author{
From the Department of Surgery, University of Kentucky, Lexington, Ky. \\ Disclosures: Author has nothing to disclose with regard to commercial support. \\ Received for publication Aug 31, 2015; accepted for publication Sept 1, 2015; available ahead of print Sept 22, \\ 2015. \\ Address for reprints: Victor A. Ferraris, MD, PhD, Tyler Gill Professor of Surgery, Department of Surgery, Uni- \\ versity of Kentucky, A301 Kentucky Clinic, 740 S Limestone, Lexington, KY 40506-0284 (E-mail: ferraris@ \\ uky.edu). \\ J Thorac Cardiovasc Surg 2015;150:e95-6 \\ $0022-5223 / \$ 36.00$ \\ Copyright (c) 2015 by The American Association for Thoracic Surgery \\ http://dx.doi.org/10.1016/j.jtcvs.2015.09.002
}

The article in this issue of the Journal by Blakely and coauthors ${ }^{1}$ describes a patient with gastric conduit ischemia 24 years after esophagectomy. This article provides convincing evidence to suggest that the ischemia was reversible, was related to celiac artery stenosis, and was amenable to arterial stent intervention at the origin of the celiac artery. Such ischemia is an exceedingly rare late complication of gastric conduit interposition to replace the resected esophagus, and this report amplifies the importance of the gastroepiploic artery in establishing and maintaining gastric conduit viability.

Gastric conduit necrosis is rare but potentially lethal, no matter when it occurs after esophagectomy. Reports suggest that gastric conduit ischemia occurs around $1 \%$ of the time after esophagectomy. ${ }^{2,3}$ The infrequency of this complication makes diagnosis paramount. In this case, the onset of ischemia was rather abrupt, but there was at least a 1-week history of prodromal symptoms, including bilious vomiting and abdominal pain. The presumption is that arterial atherosclerosis caused ischemia. Precursor symptoms, perhaps a variant of "intestinal angina," might provide a reason for earlier intervention. Blakely and coauthors $^{1}$ took a fairly aggressive approach to diagnosis and intervention including exploratory thoracotomy. The diagnosis of conduit ischemia is probably best done by upper endoscopy (http://www.sages.org/wp-content/uploads/ posters/2009/23811.jpg?78cc94), but chest and abdominal imaging are a necessary part of deciding about intervention.

The average survival of all comers undergoing esophagectomy with gastric conduit interposition is far less than the 24 years observed in Blakely and coauthors' patient. ${ }^{1}$ The presence of a gastric conduit in a patient many years after esophagectomy is a reasonable indication of need for continued follow-up, especially with careful questioning about abdominal symptoms or new swallowing difficulties. It is likely that patients who undergo gastric conduit interposition should have life-time follow up, perhaps with intermittent upper endoscopy, monitoring both for recurrent esophageal cancer and for evidence of gastric ischemia.

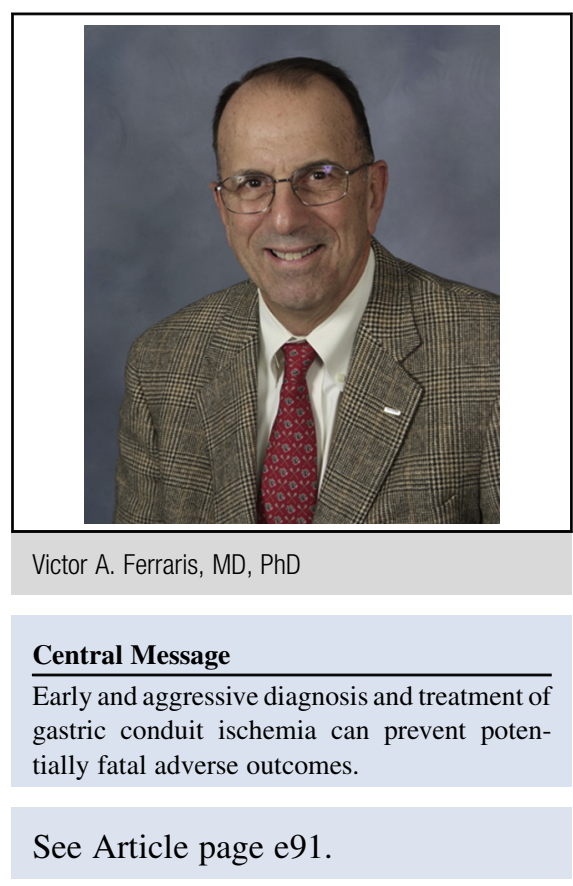

There are some interesting side notes about diagnosing and avoiding conduit ischemia after esophagectomy. Preoperative ischemic preconditioning done laparoscopically is a "far out" attempt at minimizing this conduit ischemia. ${ }^{4}$ The value of this preconditioning is uncertain, but it may be useful in certain unusual circumstances. Intraoperative evaluation of the gastric conduit is important, with assessment both before and after placement of the conduit in its new anatomic position. An interesting report suggests that laser-induced fluorescence with indocyanine green injected into the vasculature of the conduit may be used to confirm conduit viability.

Gastric conduit ischemia is a surgical emergency. Adequate resuscitation and treatment of sepsis can allow survival in most cases, perhaps with gastric conduit resection and cervical esophagostomy. In this case report, Blakely and coauthors ${ }^{1}$ did the right thing. Early and aggressive diagnosis and treatment allowed survival of their patient without the need for gastric conduit resection or cervical esophagostomy. It is rare that an easily manageable cause of gastric conduit ischemia is identified. A significant percentage of patients with full-thickness conduit ischemia require gastric resection and cervical esophagostomy. Reversal of cervical esophagostomy is fraught with complications ${ }^{6}$ and may only be possible in as few as $50 \%$ of patients. $^{7,8}$ Unusual patients such as the one presented in 
Blakely and coauthors' case report ${ }^{1}$ prompt thoughtful reflection on all aspects of managing this life-threatening complication.

\section{References}

1. Blakely AM, Young JS, Malek J, Ng T. Late gastric conduit ischemia from celiac artery stenosis salvaged by stent therapy. J Thorac Cardiovasc Surg. 2015;150: e91-3.

2. Wormuth JK, Heitmiller RF. Esophageal conduit necrosis. Thorac Surg Clin. 2006;16:11-22.

3. Rice TW. Anastomotic stricture complicating esophagectomy. Thorac Surg Clin. 2006; 16:63-73.
4. Yetasook AK, Leung D, Howington JA, Talamonti MS, Zhao J, Carbray JM, et al. Laparoscopic ischemic conditioning of the stomach prior to esophagectomy. Dis Esophagus. 2013;26:479-86.

5. Pacheco PE, Hill SM, Henriques SM, Paulsen JK, Anderson RC. The novel use of intraoperative laser-induced fluorescence of indocyanine green tissue angiography for evaluation of the gastric conduit in esophageal reconstructive surgery. Am J Surg. 2013;205:349-52; discussion 352-3.

6. Barkley C, Orringer MB, Iannettoni MD, Yee J. Challenges in reversing esophageal discontinuity operations. Ann Thorac Surg. 2003;76:989-94; discussion 995.

7. Salo JA, Isolauri JO, Heikkilä LJ, Markkula HT, Heikkinen LO, Kivilaakso EO, et al. Management of delayed esophageal perforation with mediastinal sepsis. Esophagectomy or primary repair? J Thorac Cardiovasc Surg. 1993;106:1088-91.

8. Rigberg DA, Centeno JM, Blinman TA, Towfigh S, McFadden DW. Two decades of cervical esophagostomy: indications and outcomes. Am Surg. 1998;64:939-41. 